\title{
Regulation of fix LJ by Hfq Controls Symbiotically Important Genes in Sinorhizobium meliloti
}

\author{
Mengsheng Gao, Hahn Nguyen, Isai Salas González, and Max Teplitski \\ Soil and Water Sciences Department, Genetics Institute, University of Florida-Institute of Food and Agricultural Sciences, \\ Gainesville 32611, U.S.A.
}

Accepted 5 October 2016.

\begin{abstract}
The RNA-binding chaperone Hfq plays critical roles in the establishment and functionality of the symbiosis between Sinorhizobium meliloti and its legume hosts. A mutation in $h f q$ reduces symbiotic efficiency resulting in a Fix ${ }^{-}$phenotype, characterized by the inability of the bacterium to fix nitrogen. At least in part, this is due to the ability of $\mathrm{Hfq}$ to regulate the fix $L J$ operon, which encodes a sensor kinase-response regulator pair that controls expression of the nitrogenase genes. The ability of Hfq to bind fix $L J$ in vitro and in planta was demonstrated with gel shift and coimmunoprecipitation experiments. Two $(A R N)_{2}$ motifs in the fixLJ message were the likely sites through which Hfq exerted its posttranscriptional control. Consistent with the regulatory effects of Hfq, downstream genes controlled by FixLJ (such as $n i f K, n o e B$ ) were also subject to $\mathrm{Hfq}$ regulation in planta.
\end{abstract}

The soil bacterium Sinorhizobium meliloti engages in a symbiosis with plants from genera Medicago, Melilotus, and Trigonella, which leads to the development of new plant organs (nodules). Inside nodules, rhizobia differentiate into bacteroids and carry out nitrogen fixation by converting atmospheric dinitrogen into ammonium. The establishment and productivity of $S$. meliloti-legume symbiosis depend on a signal exchange leading to the precisely timed regulation of gene expression in both partners (Gibson et al. 2008; Long 2001). The symbiosis is initiated when rhizobia chemotax along the gradient of flavonoids toward plant roots and, then, express early nodulation genes, resulting in the production of Nod factors (Peters et al. 1986). Nod factors, along with other cues, induce a number of physiological and anatomical accommodations in plants leading to intracellular invasion by rhizobia, their subsequent differentiation into bacteroids, and eventually, nitrogen fixation. Nitrogen fixation is catalyzed by nitrogenase, which is encoded by the bacterial nif genes (Zimmerman et al. 1983). While plants obtain fixed nitrogen from their bacterial symbionts, bacteria gain energy and $\mathrm{C}$ skeletons in the form of dicarboxilic acids (Yurgel and Kahn 2004). The plant host and bacteroids probably also exchange amino acids. For example, peas were shown to supply leucine, isoleucine, and valine to Rhizobium leguminosarum in exchange for aspartate (Lodwig et al. 2003).

Microarray studies comparing $S$. meliloti gene-expression patterns in free-living cells with those in bacteroids have shown

Corresponding author: M. Teplitski; E-mail: maxtep@ufl.edu

*The $\boldsymbol{e}$-Xtra logo stands for "electronic extra" and indicates that two supplementary figures, four supplementary tables, and supplementary materials are published online.

(C) 2016 The American Phytopathological Society that a number of genes are induced inside nodules (Ampe et al. 2003; Becker et al. 2004). The majority of these genes are regulated by the oxygen-sensing two-component regulatory system FixLJ, which plays a major role in controlling the expression of the late nodulation nif and fix genes within bacteroids (David et al. 1988). Concurrently on the plant side, changes in gene expression ensure production of plant leghemoglobins in the cytoplasm of the nodule cells containing bacteroids (Cutting and Schulman 1971; Zimmerman et al. 1983). Leghemoglobins have high affinity for oxygen and create a microaerobic environment, which is perceived by FixLJ and is suitable for the activity of the oxygen-labile nitrogenase (Fischer 1994).

FixLJ-mediated signal transduction has been well-studied in S. meliloti. The fix and nif genes mapped to the symbiotic megaplasmid (pSymA) (Barnett et al. 2001). S. meliloti fixL or fixJ mutants are able to form nodules, but no nitrogen fixation takes place within them (Fix ${ }^{-}$phenotype) (Zimmerman et al. 1983). This regulatory cascade consists of the response regulator FixJ and its cognate sensor kinase FixL, transcriptional activators encoded by nifA and fixK, as well as nitrogenase genes (nifHDK) (Fischer 1994). The microaerobic environment induces the fix $L J$ operon within bacteroids, FixLJ then activates nifA and fixK genes, and NifA activates nitrogenase genes (David et al. 1988). In Azorhizobium caulinodans, Rhizobium leguminosarum, and S. meliloti, nifA and fixK are also subject to regulation by the RNA-binding protein Hfq (Kaminski et al. 1994; Torres-Quesada et al. 2010; Zhang and Hong 2009). In fact, recent studies identified Hfq as an important regulator of gene expression in the legume-rhizobium symbiosis (Barra-Bily et al. 2010; Gao et al. 2010; Torres-Quesada et al. 2010, 2014).

Hfq is a posttranscriptional regulator found in gram-negative and gram-positive bacteria. Hfq is a chaperone that is capable of actively unfolding small (s)RNA and messenger (m)RNA to either facilitate their base-pairing or block access to the ribosome-binding site (Brennan and Link 2007; De Lay et al. 2013; Soper et al. 2010). Binding of sRNA and mRNA to Hfq may also increase local concentrations of RNA and this alone may facilitate base pairing (Brennan and Link 2007). The proximal and distal faces of Hfq bind specific sequences in sRNA and mRNA. At least initially, uridine-rich sequences within sRNA bind to the proximal face and are thought to then move to the lateral site (rim), while adenine-rich ARN repeats in mRNA interact with the distal face of the protein (De Lay et al. 2013; Link et al. 2009; Schumacher et al. 2002). Functional importance of (ARN)n motifs in mRNAs was experimentally validated in the $5^{\prime}$ untranslated region (UTR) of Escherichia coli rpoS and glmS mRNA (Robinson et al. 2014) and within S. meliloti expR (Gao et al. 2015). Even though nearly all functionally important $(\mathrm{ARN}) \mathrm{n}$ sites are within the 5' UTR, internal Hfq-binding sites have been also identified (De Lay et al. 2013). 
S. meliloti $h f q$ mutants form nodules but are unable to regulate symbiotically relevant genes and exhibit a nitrogen-starvation phenotype when inoculated on alfalfa and Medicago truncatula roots (Barra-Bily et al. 2010; Gao et al. 2010; Torres-Quesada et al. 2010). Nodules formed by the $h f q$ mutants were small and less pink due to the reduced levels of leghemoglobin. Bacteroids formed by the $h f q$ mutants in the indeterminate $M$. truncatula nodules were similar to the type III and type IV bacteroids described by Vasse and associates (1990), similar to those formed by fixL and fixJ mutants (Gao et al. 2010; Vasse et al. 1990), therefore suggesting a link between the phenotypes controlled by Hfq and FixLJ.

In this study, we combined in silico predictions, genetic, and biochemical analyses to further characterize regulatory functions of the $S$. meliloti RNA-binding protein $\mathrm{Hfq}$ in M. truncatula nodules. We tested a hypothesis that the effects of Hfq on the expression of symbiotic genes are mediated by the direct interactions of Hfq with fixLJ.

\section{RESULTS}

\section{Bioinformatic predictions and validation of the symbiotic Hfa regulon.}

To characterize the symbiotic Hfq regulon, bioinformatic predictions of its potential members were carried out (the PERL script can be found in the Supplementary Materials file). Of the transcripts identified in this bioinformatics analysis, Sma0854 (nodG), Smc00241 (transcriptional regulator), Sma1227 (fixJ), Sma2379 (catalase), Smc01033 (arylesterase), and small regulatory RNA SmrC15 were previously reported as differentially regulated by $\mathrm{Hfq}$ in shake cultures and $\mathrm{SmrC} 15$ was also shown to be under the Hfq control in nodules (del Val et al. 2007; Gao et al. 2010; Torres-Quesada et al. 2014). There is only partial overlap with the previously reported Hfq regulon; however, it is important to point out that previous high-throughput studies were carried out in shake cultures. However, only transcripts reported to be differentially regulated during the symbiosis were included in this in silico screen. The list of genes resulting from the bioinformatic analysis was further narrowed to 11 genes with known or hypothesized functions in the specificity of symbiotic interactions and efficiency of nitrogen fixation (Table 1) (Ampe et al. 2003; Becker et al. 2004; Bobik et al. 2006). It includes nodulation genes nodI, nodJ, nodG, symbiotic and nitrogen fixation genes fixJ, nifK, and noeB, EPSII regulatory gene mucR, putative regulatory genes Sma0281, Smc00241, and Smc00370, and putative pilus gene Sma1564. To test the hypothesis that Hfq affects accumulation of the corresponding transcripts, reverse transcription-quantitative polymerase chain reaction (RT-qPCR) was carried out using RNA extracted from nodules formed by the wild-type $S$. meliloti and its isogenic $h f q$ mutant. Two $S$. meliloti sRNAs, SMrC15 and SMrC45, known to interact with Hfq (Gao et al. 2010; Torres-Quesada et al. 2010; Voss et al. 2009) served as controls. SMrc15 is a homolog of AbcR1 in Agrobacterium tumefaciens and AbcR1, which was shown to control the uptake of the nonproteinogenic $\gamma$-aminobutyric acid (Wilms et al. 2011), a plant-generated signaling molecule recognized by Agrobacterium tumefaciens. Even though Hfq binds to both of these sRNAs, $\mathrm{SMrC} 15$ is expressed in nodules, while SMrC45 is known not to be expressed strongly under the same conditions (del Val et al. 2007).

Accumulation of mRNA corresponding to the late nodulation genes (fixJ, nifK, and noeB) was clearly increased in the wildtype background (Table 1). Accumulation of mRNA of early nodulation genes (nodI, nodJ, nodG) in the nodules was only modestly affected by the deletion of $h f q$; however, these early nodulation genes are not strongly expressed inside the nodules in the first place (Ampe et al. 2003). No strong effects of $h f q$ on the accumulation of mRNA of $m u c R$, Sma1564, Smc00370, Smc00241, and Sma0281 were observed (Table 1). Consistent with previous reports that $h f q$ affected accumulation of the small RNA SMrC15, corresponding changes in accumulation of this sRNA were observed in the nodules formed by the wildtype $S$. meliloti but not by the $h f q$ mutant (Table 1 ).

While positive effects of Hfq on the expression of fixK were previously reported (Torres-Quesada et al. 2010), Hfq control of either fixJ or nifK has not been previously demonstrated. With subsequent experiments, we decided to determine whether Hfq directly interacts with its targets (fixJ, nifK, noeB) or whether the regulatory effects are mediated via the two-component system FixLJ. To test this hypothesis, we first determined whether Hfq can directly bind to fixL, fixJ, nifH, nifK, and noeB transcripts in vitro. As shown in Figure 1, Hfq was capable of binding to these five transcripts (and SmrC45 RNA control) in vitro. In control experiments, Hfq weakly interacted with poly- $\mathrm{C}_{30}$ RNA (Fig. 1; Supplementary Fig. S1). However, binding of poly- $\mathrm{C}_{30}$ to Hfq appears nonspecific, based on the fact that the appearance of the shift was not dependent on the concentration of poly- $\mathrm{C}_{30}$ (Fig. 1G). The addition of unlabeled fixL (a presumed direct target of Hfq) did not disrupt the weak shift in the poly- $\mathrm{C}_{30}+\mathrm{Hfq}$ reactions (Fig. 1G), which is consistent with the nonspecific binding of poly- $\mathrm{C}_{30}$ to Hfq. However, when unlabeled poly- $\mathrm{C}_{30}$ was incubated with biotinylated fixL, it partially disrupted binding of fixL to Hfq only when poly- $\mathrm{C}_{30}$ was added in at least 10 -fold excess. However, unlabeled fix $L$ was a much stronger competitor than poly- $\mathrm{C}_{30}$. These observations are consistent with previously reported weak interactions of $\mathrm{Hfq}$ and poly-C RNA fragments (Zhang et al. 2002). Therefore, with follow-up experiments, we attempted to determine whether interactions between Hfq and fixL, fixJ, nifH, nifK, and noeB occur during normal symbiotic interactions.

\section{fix $L J$ mRNA coimmunoprecipitates with Hfq.}

To follow up on the results of the RT-qPCR and in vitro RNAbinding experiments, coimmunopreciptation (co-IP) experiments were carried out. A $S$. meliloti strain carrying N-terminally hexahistidine-tagged $h f q$ on a medium-copy number plasmid was used. Functionality of this construct has been previously

Table 1. Hfq-responsive expression of Sinorhizobium meliloti genes in young nodules on main roots of Medicago truncatula seedlings

\begin{tabular}{llc}
\hline Gene ID & Gene name & Fold change in gene expressiona \\
\hline SMa1227 & fixJ & $13.3 \pm 0.5$ \\
SMa0829 & nifK & $34.35 \pm 0.4$ \\
SMa0774 & noeB & $6.9 \pm 0.9$ \\
SMa0863 & nodJ & $2.0 \pm 0.3$ \\
SMa0864 & nodI & $1.8 \pm 0.2$ \\
SMa0854 & nodG & $3.2 \pm 0.4$ \\
SMc00058 & mucR & $1.5 \pm 0.1$ \\
SMa0281 & Sma0281 & $1.5 \pm 0.4$ \\
SMc00241 & Smc00241 & $1.9 \pm 0.4$ \\
SMc00370 & Smc00370 & $1.1 \pm 0.2$ \\
SMa1564 & Sma1564 & $1.3 \pm 0.2$ \\
SMrc15 & Smrc15 & $19.9 \pm 3$ \\
SMrc45 & Smrc45 & $2.1 \pm 0.8$ \\
\hline
\end{tabular}

a Wild-type versus $\Delta h f q$ mutant. The fold change in the expression of target genes relative to the expression of the internal control gene (SMc00128) was documented. The mean fold change in the expression of each target genes was calculated using cycle threshold $(\mathrm{Ct})$ values, using the $2^{-\Delta \Delta \mathrm{Ct}}$ method (Livak and Schmittgen 2001), and was normalized to the expression of SMc00128 as previously described (Gao et al. 2010). Errors represent standard error of the mean. Each mean value was from three different cDNA samples and quantitative polymerase chain reactions $(n=$ 3 ), as described before (Gao et al. 2010). Each cDNA sample was made from pooled RNA of three different nodule RNA preparations for each tested strain, as in (Ampe et al. 2003). The experiments were repeated twice. 
confirmed, as this plasmid-borne tagged $h f q$ construct was shown to complement wild-type levels of nodulation and growth under a variety of conditions (Gao et al. 2010).

For the co-IP experiments, frozen nodules were ground, cells were lysed, and the lysates were incubated with the anti-His antibody. RNA was heat-released from the Hfq-antibody complexes following extensive washes. sRNA SmrC15 and SmrC16 were readily detectable in the fraction that was heatreleased from the anti-His/Hfq ${ }^{\text {His }}$-RNA complexes (Fig. 2), consistent with previous reports that these two sRNA interacted with Hfq and were expressed in nodules (del Val et al. 2007;
Gao et al. 2015; Torres-Quesada et al. 2010). Furthermore, Smrc45 sRNA was not significantly enriched in the same fraction, consistent with the report that, even though this sRNA interacts with $\mathrm{Hfq}$ under laboratory conditions, it is not expressed in nodules (del Val et al. 2007). Finally, a nonspecific control Smrc7 sRNA in the Hfq co-IP experiment was enriched by $3.1 \pm 0.7$ fold (Fig. 2B). Smrc7 was selected as control because it is known to be expressed in both free-living bacteria and in Sinorhizobia nodules, with strong increase in expression within mature nodules, as demonstrated by Northern hybridization (del Val et al. 2007). Neither the accumulation of the Smrc7 transcript

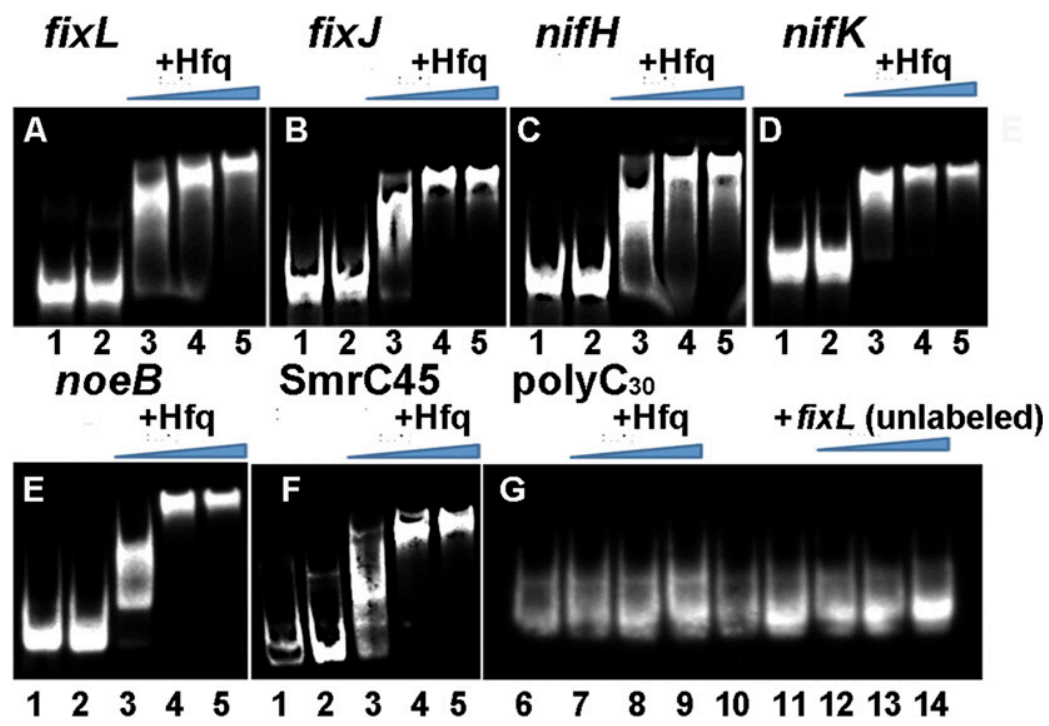

Fig. 1. Electrophoretic mobility shift assays using Hfq and $\mathbf{A}$, fixL, B, fixJ, C, nifH, D, nifK, E, noeB, F, SmrC45, and G, poly-C ${ }_{30}$ RNA. RNA fragments spanning transcriptional start sites of fixL, fixJ, nifH, nifK, noeB, and SmrC45 were synthesized in vitro, using T7 RNA polymerase with polymerase chain reaction fragments as templates. A 30 -nt polyC oligomer (poly- $\mathrm{C}_{30}$ ) was synthesized commercially, and 1 pmol of poly- $\mathrm{C}_{30}$ was added to the lowest dilution. RNA fragments were then labeled with biotin and were incubated with purified Hfq. These RNA fragments were added at 1 pmol to each reaction. Experiments were repeated at least twice. Lane 1 in each panel, RNA fragment $+10 \mu \mathrm{g}$ bovine serum albumin; lane 2, free RNA fragment; lanes 3 through 5, RNA fragments with increasing concentrations of $\mathrm{Hfq}(1,8$, and $16 \mathrm{pmol})$; lane 6 , free biotin-labeled poly- $\mathrm{C}_{30}$; lane 7 , poly- $\mathrm{C}_{30} / \mathrm{Hfq}(1: 1 \mathrm{moles}) ;$ lane 8 , poly- $\mathrm{C}_{30} / \mathrm{Hfq}(1: 2$ moles); lane 9 , poly- $\mathrm{C}_{30} / \mathrm{Hfq}\left(1: 4\right.$ moles); lane 10 , poly- $\mathrm{C}_{30} / \mathrm{Hfq}(1: 8 \mathrm{moles}) ;$ lane 11 , poly- $\mathrm{C}_{30} / \mathrm{Hfq}(1: 16 \mathrm{moles})$; lane 12 , poly- $\mathrm{C}_{30} /$ unlabeled fixL fragment/Hfq (1:1:8 moles); lane 13: poly- $\mathrm{C}_{30} /$ unlabeled fixL/Hfq (1:5:8 moles), lane 14: poly-C $\mathrm{C}_{30} /$ unlabeled fixL/Hfq (1:10:8 moles).

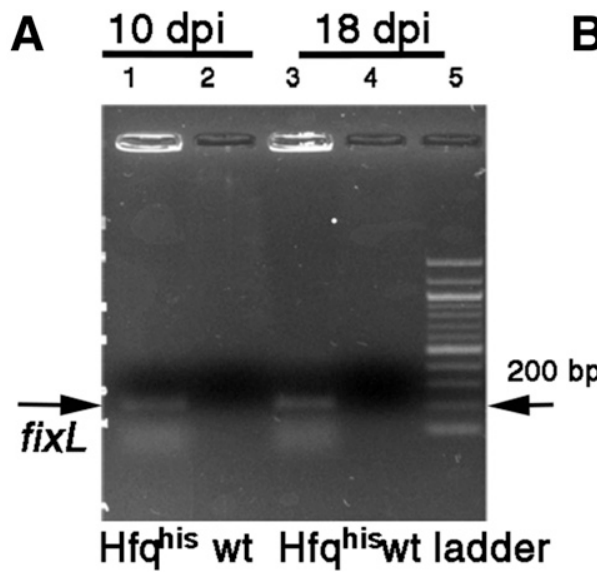

B

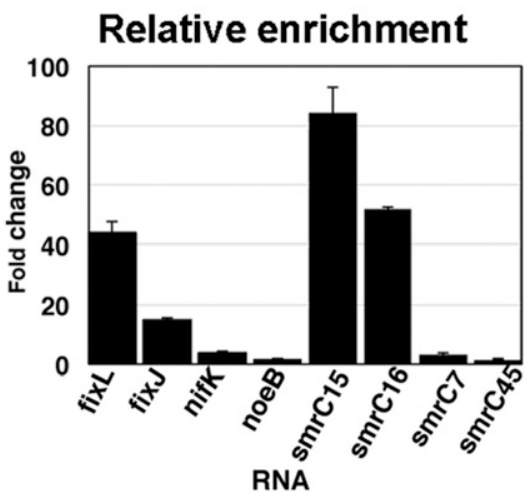

Fig. 2. Hfq complexes fixLJ mRNA in planta. A, An image of $1.2 \%$ agarose gel showing polymerase chain reaction (PCR)-amplified fixL cDNA fragments (lanes 1 and 3) in cDNA samples generated from $\mathrm{Hfq}^{\text {His }}$-RNA complexes, which coimmunoprecipitated from lysates of Medicago truncatula young nodules (10 and 18 days postinoculation [dpi]) but not in negative control cDNA samples containing untagged wild-type (wt) Hfq (lanes 2 and 4). DNA sequencing analysis of the amplified 200-bp fragment has confirmed fixL identity of the two gel bands. The end point PCR primers were MG3205 and MG3206. This experiment was repeated twice and similar results were obtained. Hfq ${ }^{\text {His }}$ protein-RNA complexes were prepared from Sinorhizobium meliloti 8530 4 hfq p\#5infected M. truncatula nodules. The control samples were from nodules infected with S. meliloti $8530 \mathrm{pBBR} 1-\mathrm{MCS} 5$. B, Reverse transcription-quantitative (q) PCR analysis of the RNA coimmunoprecipitated with $\mathrm{Hfq}^{\mathrm{His}}$. RNA, complexed in planta with Hfq and then heat-released, were reverse transcribed and were subjected to qPCR. Relative enrichments were calculated from cycle threshold $(\mathrm{Ct})$ mean values of three qPCR reactions, using the $2^{-\Delta \Delta \mathrm{Ct}}$ method (Livak and Schmittgen 2001); the data are presented as the fold change in transcript enrichment normalized to $S$. meliloti SMc00128 or the 16S rRNA gene. Values are given in fold change \pm standard error of the mean. 
nor its half life in $S$. meliloti was affected by an $h f q$ mutation (Gao et al. 2010; Torres-Quesada et al. 2014) (Fig. 2C). Therefore, coIP experiments were technically sound.

The fixLJ mRNA was found in the fraction that was heatreleased from the anti-His/Hfq ${ }^{\text {His }}$ complex from nodules $(10$ and 18 days postinoculation [dpi]) (Fig. 2) but not in the similarly prepared control samples containing untagged Hfq protein (Fig. 2). Transcripts corresponding to nifHDK mRNA and noe $A B$ were enriched only approximately 1.5 to fourfold by coIP, similar to that of nonspecific control Smrc7 RNA (3.1 \pm 0.7$)$. Expression levels of nifK and noeB can play an important role in determining their binding to Hfq in planta; more abundant transcripts may be overrepresented in the pool of mRNA bound and subsequently released from Hfq. For example, expression levels of nifK in mature nodules could be quite high. The accumulation of nifK was strongly induced in $M$. truncatula nodules (6.1-fold in 18-dpi nodules and 9.6-fold in 8-dpi nodules in microarray experiments [Ampe et al. 2003]). NifK protein is also abundant in the nodules (Djordjevic 2004). Recovery of the nifK transcripts from the pool of transcripts bound to Hfq was higher (3.6 \pm 0.9$)$ than the background. In contrast, expression levels of $n o e B$ in mature nodules are probably low, even though they were detectable by microarray (Bobik et al. 2006). NoeA and NoeB proteins are not as abundant as NifK (Djordjevic 2004).

Collectively, results of the RT-qPCR experiments and in vivo co-IP suggest that, under symbiotic conditions, Hfq strongly associates with fix $J$ transcripts and the Hfq does not associate with nifHDK or noe $A B$ transcripts under the same conditions. It is possible that Hfq exerts its control over nifHDK and noeAB via FixLJ (Bobik et al. 2006; Gong et al. 2006). Electrophoretic mobility shift assay (EMSA) experiments (Fig. 1) confirmed the results of the bioinformatic analysis, showing fixL, fixJ, nifH, nifK, and noeB contain sites that can be bound by Hfq under some conditions (i.e., in vitro). However, given that only fixJ bound to Hfq in planta and was subsequently released from this chaperone in vitro, it is also possible that binding of these transcripts to Hfq under symbiotic conditions may not be sufficiently strong to be detected under these experimental conditions.

\section{Partial restoration of the Fix phenotype of $\boldsymbol{h} f \boldsymbol{q}$ with $f i x \boldsymbol{L} J$.}

To test the hypothesis that the symbiotic defects of $h f q$ are mediated by FixLJ, we carried out epistasis experiments. A 2.5$\mathrm{kb}$ fragment of $S$. meliloti DNA containing a wild-type copy of the fixLJ operon and a presumed fixL promoter was cloned into a broad host range-medium copy number plasmid (Supplementary Fig. S2). The accumulation of fix $L J$ transcripts in strains

Table 2. Expression of fixL and fixJ in shake cultures and in planta

\begin{tabular}{|c|c|c|c|c|}
\hline \multirow[b]{3}{*}{ Sample } & \multicolumn{4}{|c|}{ Relative expression ${ }^{a}$} \\
\hline & \multicolumn{2}{|c|}{$8530 \Delta h f q$ pHfq } & \multicolumn{2}{|c|}{$8530 \Delta h f q$ pFixLJ } \\
\hline & fixL & fixJ & fixL & $f i x J$ \\
\hline Shake culture ${ }^{b}$ & $1.5 \pm 0.7$ & $1.3 \pm 0.2$ & $1.3 \pm 0.3$ & $1.7 \pm 0.3$ \\
\hline $10 \mathrm{dpi}$ & $27.0 \pm 2$ & $11.3 \pm 0.6$ & $16 \pm 2$ & $11.3 \pm 0.6$ \\
\hline $18 \mathrm{dpi}$ & $24 \pm 1.0$ & $27 \pm 0.8$ & $10.5 \pm 0.5$ & $4.3 \pm 1$ \\
\hline
\end{tabular}

a Mean fold change relative to $8530 \Delta h f q$ pBBR1MCS-5. The fold change in the expression of target genes relative to the expression of the interna control gene (SMc00128) was calculated. The mean fold change in the expression of each target gene was calculated using cycle threshold $(\mathrm{Ct})$ values, using the $2^{-\Delta \Delta \mathrm{Ct}}$ method (Livak and Schmittgen 2001), and was normalized to the expression of SMc00128 as previously described (Gao et al. 2010).

${ }^{b}$ In the shake culture experiment, cells were harvested at $\mathrm{OD}_{600}=0.5$ to 0.6 each cDNA sample was made from a pooled RNA of three different RNA preparations for each tested strain as described in (Gao et al. 2010). Errors represent standard error of the mean. Experiments were repeated twice. dpi $=$ days postinoculation
$8530 \Delta h f q$ pFixLJ $(h f q, f i x L J+)$ and $8530 \Delta h f q$ pHfq $(h f q, h f q+)$ was compared with that in the $h f q$ mutant carrying only the vector pBBR1MCS-5 (Table 2). Levels of fix LJ transcripts in $8530 \Delta h f q$ pFixLJ in nodules (10 and $18 \mathrm{dpi}$ ) were 4.3- to 16-fold higher than in the control strain. However, this represented only partial restoration compared with the strain in which the $h f q$ mutation was complemented with a plasmid-borne copy of $h f q$ (Table 2). These results further support the hypothesis that a functional $h f q$ is required for the posttranscriptional stability of fix $L J$.

The expression of fixLJ from pFixLJ in $8530 \Delta h f q$ partially rescued nitrogen starvation of $M$. truncatula, as evidenced by better growth and green color of the plants. However, restoration of the phenotype was incomplete (Fig. 3A). At $18 \mathrm{dpi}$, average shoot height of the plants inoculated with $8530 \Delta \mathrm{hfq}$ pFixLJ was $3.3 \pm 0.3 \mathrm{~cm}(n=13)$, which was significantly higher $(P<0.05)$ than average shoots of plants infected with $8530 \Delta h f q(2.2 \pm 0.3 \mathrm{~cm}, n=15)$ but less than that of plants infected with $8530 \Delta h f q$ pHfq $(4.0 \pm 0.3 \mathrm{~cm}, n=15)$. Nodules formed by $8530 \Delta h f q$ pFixLJ (10 dpi) were ovoid and clearly more advanced than the spherical nodules formed by $8530 \Delta h f q$ (Fig. 3B), however, they were not as developmentally advanced as the nodules formed by $8530 \Delta h f q$ pHfq (Fig. 3B). Furthermore, the intensity of the pink color (indicative of the abundance of leghemoglobin) was higher in the nodules formed by $8530 \Delta$ hfq pFixLJ and the sizes of the nodules were significantly bigger than the nodules formed by the mutant (Fig. 3C; Supplementary Table S1).

\section{Hfq controls nifHDK via FixLJ in planta.}

Because fixLJ supplied in trans partially complemented the symbiotic defect of the $h f q$ mutant, we tested whether fix $L J$ can control the nifHDK operon involved in the synthesis of nitrogenase in the $h f q$ mutant background. These experiments tested whether the regulation of nifHDK genes is entirely through FixLJ or whether Hfq also contributes to the posttranscription regulation of nifHDK in nodules. To this end, levels of nifHDK transcripts in shake cultures and in nodules formed by $S$. meliloti $8530 \Delta h f q$ pFixLJ and by $S$. meliloti $8530 \Delta h f q$ pBBR1MCS-5 (vector control) were measured. Only a modest (1.7 to 2.6-fold) effect of pFixLJ on the accumulation of these transcripts was

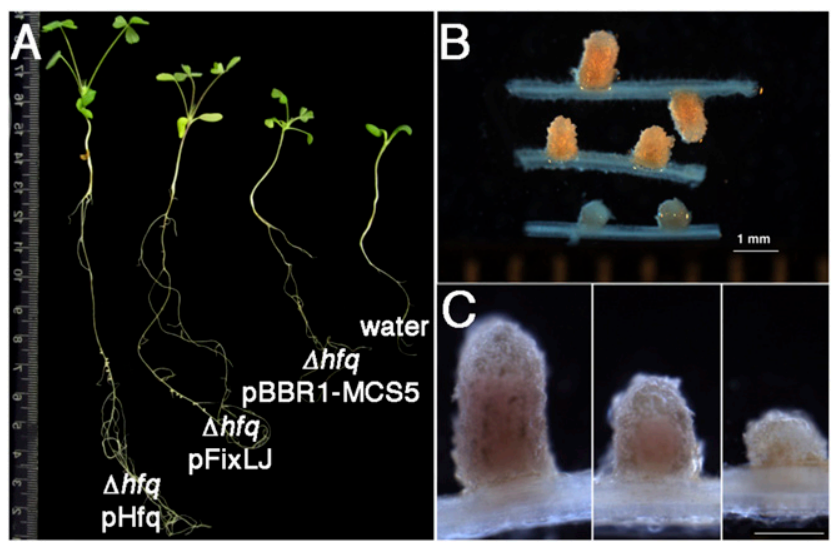

Fig. 3. Symbiotic phenotypes of Medicago truncatula infected with Sinorhizobium meliloti $8530 \Delta h f q$ and its derivatives. A, Differences in growth of seedlings 18 days postinoculation (dpi) with $S$. meliloti 8530 $\Delta$ hfq $\mathrm{pHfq}$,

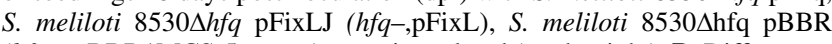
( $h f q-, \mathrm{pBBR} 1 \mathrm{MCS}-5$ vector), or uninoculated (on the right). B, Differences in the sizes of nodules $10 \mathrm{dpi}$ with $S$. meliloti 8530 $\Delta$ hfq $\mathrm{pHfq}$ (top), S. meliloti $8530 \Delta h f q$ pFixLJ (medium), or S. meliloti 8530 $\Delta h f q$ pBBR1MCS-5 (bottom). C, Differences in size and pink color intensity of the nodules $18 \mathrm{dpi}$, formed by $S$. meliloti $8530 \Delta h f q$ pHfq (left), S. meliloti $8530 \Delta h f q$ pFixLJ (middle), or $S$. meliloti $8530 \Delta h f q$ pBBR1MCS-5 (right). This experiment was repeated twice and similar results were obtained. 
observed in midlog shake cultures (Table 3). However, nif genes are known not to be expressed in well-oxygenated laboratory cultures (David et al. 1988; Fischer 1994). Substantial increases in the accumulation of these transcripts were observed in nodules formed by the $h f q$ mutant carrying pFixLJ. Levels of nifHDK transcripts in nodules formed by $8530 \Delta h f q$ pHfq were higher than those in the nodules formed by $8530 \Delta h f q$ pFixLJ. In 18-dpi nodules, levels of nifH transcripts in $8530 \Delta h f q$ pHfq were 2.1fold higher than in $8530 \Delta h f q \mathrm{pFixLJ}$ and the level of nifDK was 3.5-fold higher than in the control, while the difference in the accumulation of the nifK transcript was approximately 2.2 . Similar trends were observed in 8- and 18-dpi nodules. However, pFixLJ in the $h f q$ background did not fully complement the mutation. This is either due to the effects of Hfq on nifH and nifDK that are independent of FixLJ or, alternatively, the fix $L J$ transcript may not be fully stabilized in the $h f q$ background, even when supplied in trans. Nevertheless, it is clear that, at least in part, the regulatory effects of Hfq on the nitrogenase genes are through the control of fixLJ.

To further support the results of the RT-qPCR experiments, a merodiploid nifH::gus reporter fusion was constructed in S. meliloti $8530 \Delta h f q$. Expression of the reporter was tested in $\Delta h f q$ and in the $\Delta h f q$ strain carrying pFixLJ. As shown in Table 4 and consistent with the results of the RT-qPCR analyses, pFixLJ increased expression of the nifH::gus reporter.

\section{Characterization of $\mathrm{Hfq}$ binding motifs upstream and within the fixLJ open reading frame (ORF).}

Collectively, co-IP, gel shifts, gene expression, and epistasis experiments indicated that Hfq likely interacts with fixLJ. However, in the co-IP experiments, fixL mRNA was enriched 44-fold within the $\mathrm{Hfq}^{\text {his }}$-bound fraction, while fixJ mRNA was enriched only about 15 -fold. Therefore, to better understand how Hfq impacts fix $L J$, we focused on the characterization of the effects of this RNA-binding chaperon on fixL. Two putative Hfq-binding $(\mathrm{ARN})_{2}$ motifs (motif 1, AAGACG and motif 2, AAAAAG) were detected upstream of and within fixL (Fig. 4A). Motif 1 is identical to one of the two functional Hfq-binding sites in the $S$. meliloti $\operatorname{expR}$ (Gao et al. 2015). There were at least three other (ARN)n regions within fixLJ transcript (data not shown); however, their effects on interactions with Hfq were not tested in this study.

To test whether motifs 1 and 2 have an Hfq-dependent role in the expression of fixL, we constructed a set of $S$. meliloti translational fixL::gus reporters that lack either one or both of the motifs. These fusions were borne on integrative plasmids pFixL24, pFixL30, pFixL2a, and pFixL2 (Fig. 4B). Each of the fixL-gus fusions was mobilized into either the wild type or an $h f q$ mutant of $S$. meliloti, generating single-copy merodiploid fix $L^{+}$fix L:: gus reporters integrated into pSymA (Fig. 4C). The expression of fixL gene was analyzed using RT-qPCR and with $\beta$-glucuronidase (GUS) assays (Figs. 4D and E). In the absence of $h f q$, expression of fix $L$ was reduced by 60 - to 100 -fold for all constructs. In the wild-type background, expression of fix $L$ was the highest in the construct carrying an intact upstream region of fixL (including both motifs). Mutations of either of the motifs reduced fixL expression. Deletion of both motifs had the strongest effect on the expression of fixL (Fig. 4D).

Subsequent GUS assays of the fixL-gus fusion activities confirmed RT-qPCR results (Fig. 4E). Motifs 1 and 2 were critical to the expression of fixL in the wild type but not in $h f q$ backgrounds. Deletion of motif 1 has a stronger (approximately 20\%) effect on the expression of fixL than the deletion of motif 2 (Fig. 4E). It is possible, however, that the reduction in the expression of fixL following mutagenesis of these motifs could also be due to the mutations in the promoter region of fixL. To test this hypothesis and to determine whether Hfq induces expression from the fixL promoter, a pSymA-integrated transcriptional fixL-gus fusion, fixL23, was tested for Hfq-induced GUS activity in planta.

A deletion of $h f q$ resulted in an approximately 1.4 reduction in the activity of the fixL transcriptional fusion in nodules 10 dpi and approximately 2.3 reduction in the activity $18 \mathrm{dpi}$ (Table 5). This ability of Hfq to exert transcriptional control over fix $L$ expression explains activation of the fix $L$ translational reporters in the $h f q$-dependent but motif-independent manner (Figs. 4D and E). However, because Hfq is not a DNA-binding protein, this activation of the fix $L$ transcriptional fusion suggests that there may be another layer of fixL regulation, with Hfq controlling another upstream regulator, in addition to controlling posttranscriptional regulation of fix L.

\section{DISCUSSION}

RNA-binding chaperon Hfq has already been shown to effect global changes in $S$. meliloti gene expression in shake cultures (Gao et al. 2010). Even though symbiotic defects of the $h f q$ mutant

Table 4. Endosymbiotic $\beta$-glucuronidase (GUS) activity of nifH-gus promoter fusion

\begin{tabular}{lcc}
\hline & \multicolumn{2}{c}{ GUS activity $^{\mathbf{a}}$} \\
\cline { 2 - 3 } Strain & $\mathbf{1 0}$ dpi & $\mathbf{1 8 ~ d p i}$ \\
\hline $8530 \Delta h f q-0102$ & $76 \pm 33$ & $113 \pm 17$ \\
$8530 \Delta h f q-0102$ pFixLJ & $1,192 \pm 233$ & $1,104 \pm 218$ \\
\hline
\end{tabular}

${ }^{a}$ Measured as nanomoles per minute per optical density at $595 \mathrm{~nm} \times 1,000$ dpi $=$ days postinoculation. Activities are expressed as previously described (Bittner and Oke 2006). Averages of three independent assays for three different nodule samples are shown. Nodules were harvested from primary infection zones that are susceptible to infection (Caetano-Anollés and Bauer 1988; Gao et al. 2010). Errors represent standard error of the mean.

Table 3. Expression of nifH, nifD and nifK in Sinorhizobium meliloti $8530 \Delta h f q$ in shake culture and in nodules (epistasis experiments)

\begin{tabular}{|c|c|c|c|c|c|c|}
\hline \multirow[b]{3}{*}{ Sample } & \multicolumn{6}{|c|}{ Relative expression (fold change) ${ }^{\mathbf{a}}$} \\
\hline & \multicolumn{3}{|c|}{$8530 \Delta h f q$ pHfq } & \multicolumn{3}{|c|}{ 8530 $\Delta h f q$ pFixLJ } \\
\hline & nifH & nifDK & nifK & nifH & nifDK & nifK \\
\hline Shake culture ${ }^{\mathrm{b}}$ & $1.7 \pm 0.4 *$ & $2.6 \pm 0.7$ & $2.0 \pm 0.3$ & $1.2 \pm 0.3$ & $2.0 \pm 0.2$ & $1.6 \pm 0.9$ \\
\hline $8 \mathrm{dpi}$ & $45.3 \pm 1.9$ & $36.5 \pm 2.0$ & $21.6 \pm 1.4$ & $26 \pm 2.8$ & $10.6 \pm 0.3$ & $7.7 \pm 1.8$ \\
\hline $10 \mathrm{dpi}$ & $45.3 \pm 4$ & $25.6 \pm 1.3$ & $34.3 \pm 1.5$ & $28.6 \pm 1.3$ & $6.6 \pm 1.2$ & $16.0 \pm 1.2$ \\
\hline $18 \mathrm{dpi}$ & $270.6 \pm 1.2$ & $68.6 \pm 2.2$ & $69.1 \pm 1.4$ & $127.1 \pm 1.87$ & $19.7 \pm 2$ & $30.5 \pm 2.7$ \\
\hline
\end{tabular}


are well-documented and include defects in nitrogen fixation and assimilation of fixed nitrogen (Barra-Bily et al. 2010; Gao et al. 2010; Torres-Quesada et al. 2010), mechanisms by which Hfq controls these functions are not clear. High throughput studies in nodules are technically complicated. Therefore, we carried out bioinformatics predictions in an attempt to delineate the symbiotic Hfq regulon. Our in silico predictions that fix and nif genes are among at least 11 plausible Hfq target genes in M. truncatula nodules were supported by previous observations that the phenotypes of plants infected with the $h f q$ mutants and ultrastructure of bacteroids are similar to those infected with $S$. meliloti fixLJ and some nif mutants (Gao et al. 2010; Hirsch and Smith 1987; Vasse et al. 1990). Therefore, we focused on testing the hypothesis that Hfq controls fix and nif genes during the symbiosis.

RT-qPCR analysis of the expression of these genes in the nodules formed by $S$. meliloti revealed that the deletion of $h f q$ resulted in a reduced expression of fixJ, nifK, and noeB compared with the wild type. In the nodules formed by $S$. meliloti carrying $h f q^{\text {His }}$ (10 and $18 \mathrm{dpi}$ ), only fix $L J$ transcripts coimmunoprecipitated with Hfq, while the same experiments did not identify nifK or noeB transcripts as strongly bound to Hfq. Because the two-component system FixLJ is known to control nifK and noeB, it is reasonable to hypothesize that Hfq likely controls these via FixLJ. This hypothesis was then tested in epistasis experiments with fixLJ borne on pBBR1MCS-5. This vector appears to be stable and replicated in rhizobia for at least 4 weeks after inoculation (Gao et al. 2010) and in shake cultures (Gao et al. 2015). Consistent with our hypothesis, plasmid-borne fix $L J$ was able to partially restore $h f q$ mutation both in alleviating the nitrogen-deficiency symptoms and in the expression of the downstream nifHDK operon.

Because earlier work demonstrated that $S$. meliloti Hfq exerts posttranscriptional control over regulatory gene $\exp R$ mRNA (Gao et al. 2015) via two Hfq-binding sites with sequences similar to the (ARN)n motif of Escherichia coli (Link et al. 2009), we searched for (ARN)n motifs within the fix LJ transcript. Two $(\mathrm{ARN})_{2}$ motifs were found in positions that are likely consequential for posttranscriptional regulation of the fix $L J$ operon. Motif 1 begins 42 nt upstream of the fixL ORF and motif 2 begins at the fourth nucleotide in the ORF. Integrated translational fusions confirmed Hfq-dependent functionality of both motifs. While mutations of either one of the motifs resulted in about a twofold reduction of the activity of the translation fusion (compared with the wild type), mutagenesis of both motifs resulted in an approximately sixfold reduction of the activity in M. truncatula nodules. The mechanism of this regulation is not yet known; however, Hfq is known to be able to relax folding of mRNA around translation initiation site (Soper et al. 2010) and this may allow presentation of the fixL start codon AUG (Fig. 5). Alternatively, $\mathrm{Hfq}$ is also known to prevent degradation of the bound transcripts by RNase by masking multiple plausible recognition sites of this enzyme (Baumgardt et al. 2014). Homologs of RNase recognition sites are found in fixL mRNA, including one in motif 1 and another in motif 2 (Fig. 5), although

Table 5. Endosymbiotic $\beta$-glucuronidase (GUS) activity of fixL-gus promoter fusion

\begin{tabular}{lcc}
\hline & \multicolumn{2}{c}{ GUS activity $^{\mathbf{a}}$} \\
\cline { 2 - 3 } Strain & $\mathbf{1 0}$ dpi & $\mathbf{1 8 ~ d p i}$ \\
\hline 8530 pFixL23 & $398 \pm 83$ & $375 \pm 96$ \\
$8530 \Delta h f q$ pFixL23 & $280 \pm 94$ & $164 \pm 51$ \\
\hline
\end{tabular}

${ }^{a}$ Measured in nanomoles per minute per optical density at $595 \mathrm{~nm} \times 1,000$. $\mathrm{dpi}=$ days postinoculation. Activities are expressed as previously described (Bittner and Oke 2006). Averages of three independent assays for three different nodule samples are shown. Nodules were harvested from primary infection zones that are susceptible to infection (Caetano-Anollés and Bauer 1988; Gao et al. 2010). Errors represent standard error of the mean.

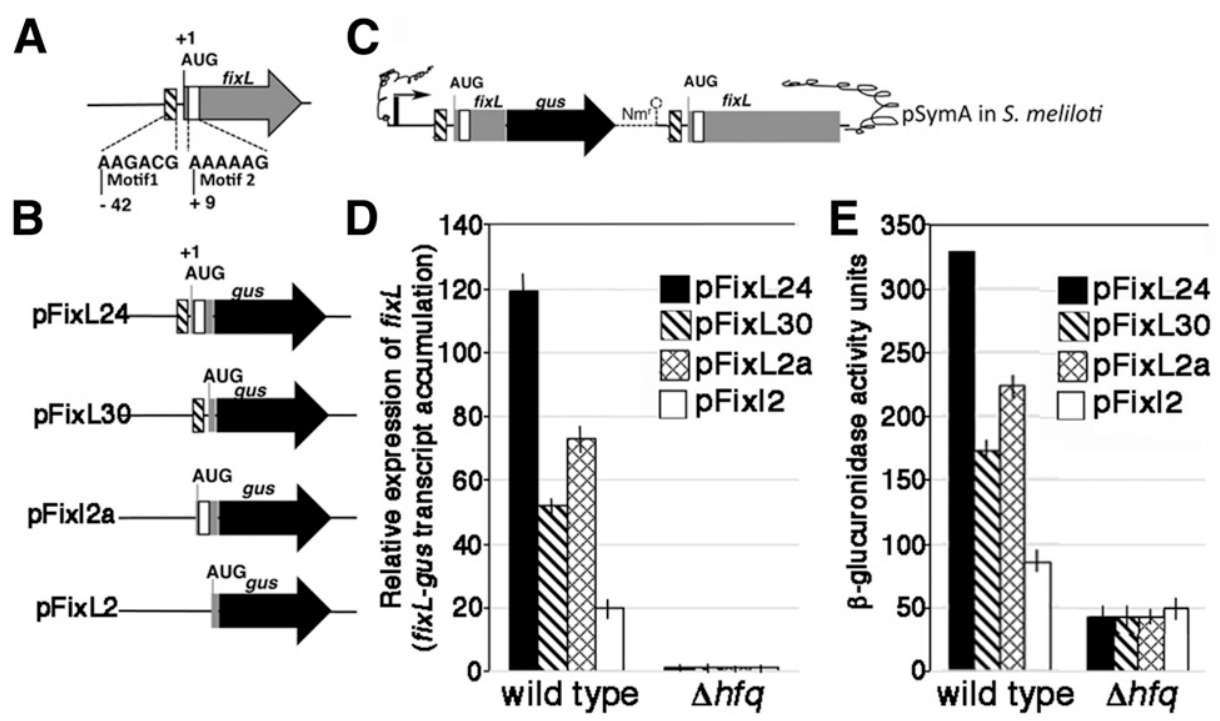

Fig. 4. fixL-gus protein fusions responsive to Hfq during symbiosis. A, A map of the translation initiation region of $f i x L$, showing sequences of the two putative Hfq binding motifs, motif 1 (hatched box) and motif 2 (white box). Numbers indicate nucleotide positions relative to the start codon AUG. B, Maps of fixL-gus fusions used in this study. pFixL24 contains gus fused with a 370-bp fragment (340 bp upstream of AUG plus 30 bp within the open reading frame [ORF]). pFixL30 contains gus fused with a shortened fixL fragment created by the deletion of motif 2 ; in pFix $2 \mathrm{a}$, gus is fused with an engineered fixL fragment created by two point mutations in motif 1 (AAGACG to tAGtCG). pFixL2 contains gus fused with a mutated, shortened fixL fragment with an engineered motif 1 and lacks motif 2. C, Schematics of pFixL24 being integrated into pSymA of Sinorhizobium meliloti. The plasmid is integrated upstream of, not in, the fixL ORF, creating a merodiploid. The fixL gene in the pSymA is full-length. D and E, Effect of Hfq on the expression of fixL-gus fusions in planta. Nodules containing reporters were processed for measuring relative accumulation of the fixL-gus transcripts by reverse-transcription-quantitative polymerase chain reaction (qPCR) analysis. Each mean value was from three different cDNA samples and qPCR reactions $(n=3)$, as described before (Gao et al. 2010). Error bars are standard error of the mean (SEM). Each cDNA sample was converted from pooled RNA from three different nodule samples for each tested strain, as described by Ampe and colleagues (2003). Each nodule sample was from nodules induced by bacterial cells in a culture of a tested strain. There were three cultures for each tested strain) and for measuring activity of $\beta$-glucuronidase (GUS) expressed from the fixL-gus fusions by GUS assay (means of two GUS assay reactions, repeated twice are shown, error bars are SEM). 
we do not yet know whether these recognition sites are truly functional RNase recognition sites.

Hfq typically facilitates base-pairing between mRNA and sRNA bound to different sites ("faces") of the protein. The sRNA that may be controlling expression of fix $L$ in the Hfq-dependent manner is not yet known. Motif 2 (AAAAAG) appears to overlap a C/A-rich element (CAAAAAGC). Some C/A-rich elements were shown to function as sRNA-binding sites in target mRNA, as exemplified by the binding of sRNA GcvB (Sharma et al. 2011).

While this study provided a first glimpse into the symbiotic functions of Hfq by controlling fix $L J$, much remains to be learned about the intricacies of $\mathrm{Hfq}$ regulation in planta. S. meliloti $\mathrm{Hfq}$ controls many genes, including small regulatory RNA expressed in nodules as well as sRNA that are induced in microaerobic environments (Torres-Quesada et al. 2014). While studies in microaerobic laboratory shake cultures are informative, they do not always reveal the complexity and consequences of the bidirectional exchange between the bacterium and its plant host. Further experiments are needed to continue defining the role of Hfq and the sRNA in controlling the symbiotic productivity.

\section{MATERIALS AND METHODS}

\section{Bioinformatics analysis.}

mRNA that were previously reported as expressed in nodules and in the bacteroids (Ampe et al. 2003; Becker et al. 2004;

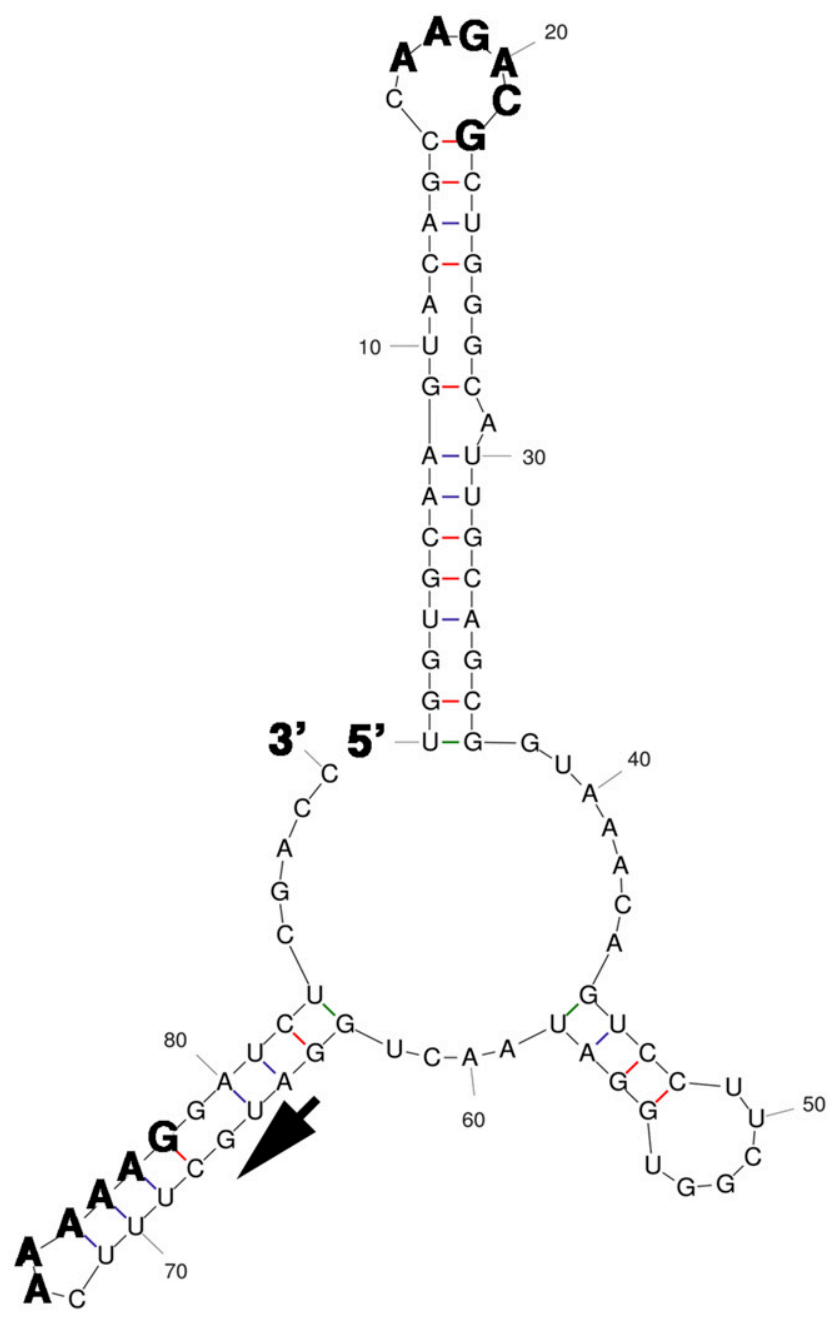

Fig. 5. Predicted secondary structure of Hfq-binding sites in fixLJ. Secondary structure of the $5^{\prime}$ untranslated region and the adjacent region was modeled, using Mfold and default settings. Hfq-binding sites (motifs 1 and 2 ) are shown in bold. The start codon is indicated with an arrow.
Bobik et al. 2006) were scanned with ad hoc PERL script to detect the presence of the previously reported mRNA-Hfq binding motif (ARN)n, where $\mathrm{A}$ is an adenine, $\mathrm{R}$ is any purine nucleotide (guanosine or adenosine), $\mathrm{N}$ is any nucleotide, and $\mathrm{n}$ is tract length from 2 to 8 (Link et al. 2009). It is of note that the biochemical evidence of $S$. meliloti Hfq binding to (ARN)n motifs is not available; however, site-directed mutagenesis suggests that $S$. meliloti Hfq interacts with (ARN)n-like motifs (Gao et al. 2015).

\section{Bacterial culture conditions.}

All bacteria were maintained as frozen glycerol stocks. Cultures of Escherichia coli were grown in Luria Bertani broth with appropriate antibiotics. S. meliloti cultures were started from individual colonies on fresh tryptone-yeast (TY) agar (Beringer 1974) plates, which were inoculated into $5 \mathrm{ml}$ of TY broth with appropriate antibiotics. Cultures were grown at $200 \mathrm{rpm}$ and $30^{\circ} \mathrm{C}$ until optical densities at $600 \mathrm{~nm}\left[\mathrm{OD}_{600}\right]$ reached 0.5 to 0.6 (for experiments in midlog phase).

\section{Plant material and inoculation protocol.}

M. truncatula $\mathrm{cv}$. A17 seedlings were aseptically germinated in the dark and were then transferred into growth pouches and were grown as previously described (Gao et al. 2005, 2010). Seedlings were watered with $1 / 4$ strength of nitrogen-free Jensen's medium. After $24 \mathrm{~h}$ of growth, plants were inoculated with the $S$. meliloti midlog cell suspensions $(200 \mu$ l of water per seedling) near root tips as before (Gao et al. 2005, 2010). To ensure that nodules were developmentally synchronized (Caetano-Anollés and Bauer 1988), growth pouches were marked to indicate the position of root tips at the time of inoculation (RT1). After $36 \mathrm{~h}$, positions of root tips were marked again (RT2). Eight, 10, and $18 \mathrm{dpi}$, nodules formed on or within the RT1-RT2 zone were separated from roots with a toothpick by a gentle push at the base of a nodule. Nodules were further processed or frozen in liquid nitrogen.

\section{Strain and strain construction.}

Strains used in this study are listed in Table 6. All S. meliloti mutants are isogenic derivatives of S. meliloti 8530 (Pellock et al. 2002). Sequences of primers used for the strain construction are in Supplementary Table S2.

Construction of pFixLJ. A 2.5-kb DNA fragment containing fixLJ from wild-type $S$. meliloti 8530 was PCR-amplified with primers MG3078 and MG3131 and Taq DNA polymerase (New England Biolabs). The amplified fix $J$ fragment was digested with SpeI and KpnI purified by Illustra GFX PCR DNA and the gel-band purification kit (GE Healthcare), and was then ligated into SpeI-KpnI-digested pBBR1MCS-5. The orientation of the fix $L J$ insert was determined by restriction digest and DNA sequencing.

Construction of gus fusions. To construct fixL-gus fusions, a 370-bp region spanning the start codon of $S$. meliloti fixL (340bp DNA upstream of ATG for fixL, which contains motif 1 plus $30 \mathrm{bp}$ within the coding region (which contains motif 2), was amplified with primers MG3078 and MG3080, using Taq polymerase (New England BioLabs). The amplified fragment was purified by Illustra GFX PCR DNA and the gel purification kit (GE Healthcare) and was then cloned in front of the promoterless GUS gene (gus) in pVO155 between the SpeI and XbaI sites, using T4 DNA ligase to yield an intermediate plasmid, pMG78/8017. pMG78/80-17 was digested with $\mathrm{XbaI}$ and was then treated by S1 nuclease (Promega), purified, and self-ligated, using T4 DNA ligase, resulting in derivatives, each with a unique deletion from the XbaI site of its parental plasmid. Sequencing of 11 of these derivatives confirmed transcriptional fixL-gus fusion plasmid pFixL23 with the junction sequence ATGCTTTCATAGGC 
GGATCTCGACCATGGTCCGT (start codons for fixL and gus are shown in bold italics and the stop codon TAG for fixL is shown in bold, the Shine-Dalgarno sequence for gus is underlined). Translational fixL-gus fusion plasmid pFixL24 with its in-frame junction sequence ATGCTTTCAAAAAGCATCTCGGTCCG TCCT (motif 2 is underlined) and ranslational fixL-gus fusion plasmid pFixL30 with its in-frame junction sequence ATGGTCCGTTTC were similarly constructed.

The motif 1 in pFixL24 was mutated (AAGACG to tAGtCG) by site-directed mutagenesis via PCR, using the following primer sets: MG3191and MG3192-tt, MG3193-tt and MG3196-BglII. PCR-generated motif 1 fragments were purified as above and were diluted and mixed, and the mixture was used as a template for a second round of PCR, using primer set MG3191-BamHI and MG3196- $B g l$ III. The PCR-generated motif 1 mutant fragment was digested with $B a m \mathrm{HI}$ and $B g l I I$ to replace the wild-type sequence in pFixL24 by cloning. This procedure yielded pFixL2a. DNA sequencing confirmed the presence of the mutations in motif 1 . Motif 1 in pFixL30 was mutagenized as above, except pFixL30 was used in the process and that created pFixL2. PCR-generated mutations in motif 1 in pFixL2 were confirmed by DNA sequencing. fixL-gus fusions were introduced into $S$. meliloti by triparental matings with helper pRK600. Integration of each fixL-gus fusion was verified by PCR using fixL recombination-specific primer MG3140F and gus primer PVO155R2 (Gao and Teplitski 2008).

To construct nifH-gus fusion, a 230-bp S. meliloti nifH fragment (a 200-bp sequence upstream of nifH ATG plus $30 \mathrm{bp}$ within the codon region) were PCR amplified with primers MG3101 and MG3102. The amplified fragment was purified and was cloned in front of the promoterless gus gene on pVMG (Gao et al. 2005), between SpeI and XbaI sites, using T4 DNA ligase. This yielded a transcriptional nifH-gus fusion pVMG01/02-nifH. The presence of the stop codon in frame was confirmed by
DNA sequence analysis (ATGGCAGCTCTGCGTTTCTAGA, start codon of nifH is shown in bold and the stop codon in bold italics). pVMG01/02-nifH was introduced into $S$. meliloti genome by triparental mating as above. Correct integration of pVMG01/02-nifH was verified by PCR, using nifH-specific primer MG3141F and PVO155R2.

\section{RNA isolation and RT-qPCR experiments.}

The bacterial pellet from a 5-ml midlog culture or $200 \mathrm{mg}$ of thin powder of nodules made by grinding them in liquid nitrogen was suspended in and incubated in $1 \mathrm{ml}$ of TRIZOL (Invitrogen) for $5 \mathrm{~min}$ at room temperature. RNA was extracted according to Invitrogen's instructions and the pellet was resuspended in nuclease-free water (Ambion). DNA was eliminated by treatment with $5 \mathrm{U}$ of RNase-free DNase (Qiagen). RNA was further purified with RNeasy MinElut cleanup kit (Qiagen), according to the manufacture's instructions, with one modification, i.e., the sample was brought up in $700 \mu \mathrm{l}$ (instead of $250 \mu \mathrm{l}$ ) of $100 \%$ ethanol prior to binding to the column, to prevent exclusion of small RNAs. RNA was quantified with Bioanalyzer.

First-strand cDNA was synthesized from $370 \mathrm{ng}$ of total bacterial RNA using SuperScript VILO cDNA synthesis kit (Invitrogen). Gene-specific primers used for qPCR are listed in Supplementary Table S3. They were designed using Primer Expression 3.0 software. DNA sequences were downloaded from the LIPM Bioinformatics database. SMc00128 and the $16 \mathrm{~S}$ rRNA genes were used as internal controls because cycle threshold $(\mathrm{Ct})$ values of these genes are similar under a number of conditions (Becker et al. 2004) and did not differ in laboratory cultures of $S$. meliloti $h f q$ mutant and its parental wild type (Gao et al. 2010). qPCR reactions were carried out with SYBR green PCR master mix (Applied Biosystems). Reactions were run on a StepOnePlus real-time PCR system (Applied Biosystems).

Table 6. Bacterial strains and plasmids used

\begin{tabular}{|c|c|c|}
\hline Strain or plasmid & Description $^{a}$ & Reference \\
\hline \multicolumn{3}{|c|}{ Sinorhizobium meliloti strains } \\
\hline $\mathrm{Rm} 8530$ & $\mathrm{Rm} 1021, \exp R+\mathrm{Sm}^{\mathrm{r}}$ & Pellock et al. 2002 \\
\hline $\operatorname{Rm} 8530 \Delta h f q$ & In-frame $h f q$ deletion mutant, $\mathrm{Sm}^{\mathrm{r}}$ & Gao et al. 2015 \\
\hline Rm8530xpFixL24 & Translational fixL::gus reporter construct, pFixL24 integrated in pSymA in $\mathrm{Rm} 8530, \mathrm{Nm}^{\mathrm{r}}$ & This work \\
\hline Rm8530xpfixL30 & Translational fixL:: gus reporter construct, pFixL30 integrated in pSymA in Rm8530, $\mathrm{Nm}^{\mathrm{r}}$ & This work \\
\hline Rm8530xpfixL2a & Translational fixL::gus reporter construct, pFixL2a integrated in pSymA in Rm8530, $\mathrm{Nm}^{\mathrm{r}}$ & This work \\
\hline Rm8530xpfixL2 & Translational fixL::gus reporter construct, pFixL2 integrated in pSymA in Rm8530 Nm & This work \\
\hline Rm8530 4 hfqpfixL24 & Translational fixL::gus reporter construct, pFixL24 integrated in pSymA, Hfq, $\mathrm{Nm}^{\mathrm{r}}$ & This work \\
\hline Rm8530 $\Delta$ hfxqfixL30 & Translational fixL:: gus reporter construct, pfixL30 integrated in pSymA, $h f q, \mathrm{Nm}^{\mathrm{r}}$ & This work \\
\hline 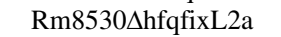 & Translational fixL::gus reporter construct, pFixL2a integrated in pSymA, $h f q, \mathrm{Nm}^{\mathrm{r}}$ & This work \\
\hline 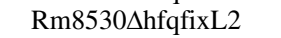 & Translational fixL::gus reporter construct, pFixL2 integrated in pSymA, $h f q, \mathrm{Nm}^{\mathrm{r}}$ & This work \\
\hline Rm8530xpfixL23 & Transcriptional fixL::gus reporter construct, pFixL23 integrated in pSymA in $\mathrm{Rm} 8530, \mathrm{Nm}^{\mathrm{r}}$ & This work \\
\hline Rm8530 4 hfxqfixL23 & Transcriptional fixL::gus reporter construct, pFixL23 integrated in pSymA, $h f q, \mathrm{Nm}^{\mathrm{r}}$ & This work \\
\hline Rm8530-01/02 & Transcriptional fixL::gus reporter construct, p01/02-nifH integrated in pSymA in Sm8530, $\mathrm{Nm}^{\mathrm{r}}$ & This work \\
\hline 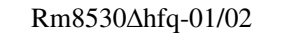 & Transcriptional fixL::gus reporter construct, p01/02-nifH integrated in pSymA, Hfq, $\mathrm{Nm}^{\mathrm{r}}$ & This work \\
\hline \multicolumn{3}{|c|}{ 20. } \\
\hline DH5 $\alpha$ & Competent cells & Invitrogen \\
\hline \multicolumn{3}{|l|}{ Plasmids } \\
\hline pBBR1MCS-3 & Broad-host-range cloning vector, $\mathrm{Tc}^{\mathrm{r}}$ & Kovach et al. 1995 \\
\hline pBBR1MCS-5 & Broad-host-range cloning vector, $\mathrm{Gm}^{\mathrm{r}}$ & Kovach et al. 1995 \\
\hline pRK600 & Conjugal transfer helper plasmid, $\mathrm{Gm}^{\mathrm{r}}$ & Finan et al. 1986 \\
\hline pVMG & gus fusion vector, ColE1, oriT, $\mathrm{Nm}^{\mathrm{r}}$ & Gao et al. 2005 \\
\hline $\mathrm{pHfq}$ & 1.6-kp SpeI-XbaI fragment of $h f q$ from $1021, \mathrm{Tc}^{\mathrm{r}}$ & Gao et al. 2010 \\
\hline p\#5 & $\mathrm{Hfq}^{\text {His }}$ expression construct, $\mathrm{Gm}^{\mathrm{r}}$ & Gao et al. 2015 \\
\hline pFixLJ & 2.5-kb Spe I-KpnI fragment of fix $L J$ gene, $\mathrm{Gm}^{\mathrm{r}}$ & This work \\
\hline pMG78/80-17 & 340-bp A 370-bp S. meliloti fixL motif determinant in pVMG, intermediate plasmid & This work \\
\hline pFixL23 & A transcriptional fixL-gus fusion in $\mathrm{pVMG}, \mathrm{Nm}^{\mathrm{r}}$ & This work \\
\hline pFixL24 & A translational fixL-gus fusion in pVMG, motif $1^{+}$, motif $2^{+}, \mathrm{Nm}^{\mathrm{r}}$ & This work \\
\hline pFixL30 & A translational fixL-gus fusion in pVMG, motif $1^{+}$, motif $2^{-} \mathrm{Nm}^{\mathrm{r}}$ & This work \\
\hline pFixL2a & A translational fixL-gus fusion in pVMG, motif $1^{-}$, motif $2^{+} \mathrm{Nm}^{\mathrm{r}}$ & This work \\
\hline pFixL2 & A translational fixL-gus fusion in pVMG, motif $1^{-}$, motif $2^{-} \mathrm{Nm}^{\mathrm{r}}$ & This work \\
\hline pVMG01/02-nifH & A transcriptional nifH-gus fusion in $\mathrm{pVMG}, \mathrm{Nm}^{\mathrm{r}}$ & This work \\
\hline
\end{tabular}

\footnotetext{
${ }^{\mathrm{a}} \mathrm{Sm}=$ streptomycin, $\mathrm{Nm}=$ neomycin, $\mathrm{Gm}=$ gentamicin, and $\mathrm{Tc}=$ tetracycline .
} 
Reaction conditions were: 40 cycles at $95^{\circ} \mathrm{C}$ for $15 \mathrm{~s}, 60^{\circ} \mathrm{C}$ for $60 \mathrm{~s}$, and $72^{\circ} \mathrm{C}$ for $60 \mathrm{~s}$, followed by a melt curve). RNA samples containing no RT were run as controls to ensure that samples were free from DNA contamination. Melt curve tests did not exhibit a second melting temperature for primer pairs used. qPCR data were processed using StepOne software version 2.2.2. Relative expression was calculated using the $2^{-\Delta \Delta \mathrm{Ct}}$ method (Livak and Schmittgen 2001). Each sample contained pooled RNA preparations from three independent cultures, as before (Gao et al. 2010), or from nodules induced by three independent cultures of the same strain. Reactions were performed in triplicate and the values were averaged.

\section{RNA co-IP.}

Samples for the co-IP experiments from nodule lysates were prepared as previously described (Gao et al. 2015), with the following modifications. Briefly, $2 \mathrm{~g}$ of thin powder of nodules was suspended in $5 \mathrm{ml}$ of cold cell extraction buffer (Invitrogen) and was lysed by sonication on ice. Debris were sedimented by centrifugation for $5 \mathrm{~min}$ at $800 \times g$. Five milliliters of the preparation, containing the $\mathrm{Hfq}^{\mathrm{His}}$-RNA complex, was incubated with $10 \mu \mathrm{g}$ of mouse anti-His antibody (Invitrogen) for $3 \mathrm{~h}$ at $4^{\circ} \mathrm{C}$ with gentle rotation. RNA was coimmunoprecipitated onto Dynabeads with protein $\mathrm{G}(1.5 \mathrm{mg})$ (Life Technologies) by incubating consecutively with $1 \mathrm{ml}$ of the RNA-Hfq-antibody complex with rotation for $10 \mathrm{~min}$ at room temperature. This was followed by five washes with phosphate buffered saline buffer. RNA was heatreleased from $\mathrm{Hfq}^{\mathrm{His}}$ by incubating the sample at $90^{\circ} \mathrm{C}$ for $2 \mathrm{~min}$ in water, as previously described (Gao et al. 2015; Schwab et al. 1997). Control experiments using extracts from the wild-type (i.e., $h f q$ was not tagged with hexahistidine) nodule lysates were performed in parallel.

\section{Purification of Hfq.}

S. meliloti $h f q$ was cloned into p15TV-L vector using the InFusion HD cloning kit (Clontech Laboratories) following the manufacturer's instructions, which resulted in p15TV-L-hfq. BL21 (DE3) p15TV-L-hfq was grown to $\mathrm{OD}_{600}=0.6$ at $37^{\circ} \mathrm{C}$ in 1 liter of terrific broth. Hfq expression was induced by the addition of isopropyl- $\beta$-D-thiogalactoside $(1 \mathrm{mM}$ final concentration) to the culture medium for $16 \mathrm{~h}$ at $16^{\circ} \mathrm{C}$. Cells were harvested by centrifugation and were suspended in $30 \mathrm{ml}$ of the lysis buffer (50 mM HEPES [pH 7], $300 \mathrm{mM} \mathrm{NaCl}, 10 \mathrm{mM}$ imidazole, $2 \mathrm{mM}$ dithiothreitol [DTT], $1 \mathrm{mM}$ phenylmethylsulfonyl fluoride). Cells were disrupted using French cell press and lysates were cleared by centrifugation. The supernatant was loaded onto Ni-NTA agarose column. The column was washed with $20 \mathrm{ml}$ of the lysis buffer and, then, with $40 \mathrm{ml}$ of wash buffer $(50 \mathrm{mM}$ imidazole). 6xHis-Hfq was eluted in $10 \mathrm{ml}$ of $250 \mathrm{mM}$ imidazole buffer. The eluent was then concentrated using Amicon Ultra-15 centrifugal filter units (3-kDa cutoff). 6xHis-Hfq was treated with TEV protease following the instructions from New England Biolabs to remove the hexahistidine tag. After the tag removal, the reaction was concentrated and imidazole was removed using Amicon Ultra15 centrifugal filter units ( $3 \mathrm{kDa}$ cut-off). It was then reloaded onto Ni-NTA agarose column to remove Tobacco etch virus (TEV) hexastidine tag and any undigested 6xHis-Hfq. After the purification, Hfq was stored in a storage buffer (25 mM HEPES, $150 \mathrm{mM}$ $\mathrm{NaCl}, 0.5 \mathrm{mM}$ EDTA, $15 \%$ glycerol, $50 \mathrm{mM}$ arginine, $2 \mathrm{mM}$ DTT) at $-20^{\circ} \mathrm{C}$

\section{RNA preparation for gel shift assays.}

For mRNA synthesis, PCR products were prepared as follows: the forward primers (atgccgttgg)TAATACGACTCACTATAGGG (N)n containing 10 random nucleotides (to increase the yield or the transcription), followed by the $\mathrm{T} 7$ promoter and gene-specific sequences, and the reverse primer containing gene-specific sequences. All oligonucleotides are listed in Supplementary Table S4. mRNA was synthesized in vitro, using PCR templates and T7 RNA polymerase (New England Biolabs). DNA templates were then destroyed using the Turbo DNA-free kit (Ambion). mRNA was purified using a Megaclear kit (Ambion) and were labeled with biotin, using Biotin-16-dUTP (Roche Life Science).

Labeled mRNA was incubated with or without increasing amounts of purified Hfq in 20- $\mu \mathrm{l}$ reactions in the binding buffer (10 mM HEPES, $10 \mathrm{mM} \mathrm{KCl}, 10 \mathrm{mM} \mathrm{NaCl}, 1 \mathrm{mM} \mathrm{MgCl}_{2}$, $0.5 \mathrm{mM}$ EDTA, $2 \mathrm{mM}$ DTT, $20 \%$ glycerol) for $20 \mathrm{~min}$ at $4{ }^{\circ} \mathrm{C}$. Where included, the "cold" competitor RNA was added to the reaction before the addition of Hfq. The samples were then mixed with glycerol to a final concentration of $10 \%$ and were loaded on native $6 \%$ polyacrylamide gel. Electrophoresis was performed in $1 \times$ tris-borate-EDTA buffer at $100 \mathrm{~V}$ for $70 \mathrm{~min}$ at $4^{\circ} \mathrm{C}$ and then transferred onto nylon membrane, using wet transfer (400 milliamps for $50 \mathrm{~min}$ ). After the transfer, membranes were exposed to UV for $50 \mathrm{~s}$. Biotin labeled bands were visualized using a Lightshift chemilunescent RNA EMSA kit (Thermo Scientific).

\section{GUS assay.}

Bacteria were isolated from nodules according to the method described by (Finan et al. 1991). GUS assays in S. meliloti strains carrying GUS fusions were performed with the substrate p-nitrophenyl- $\beta$-D-glucuronide, as previously described, and GUS activity calculations were carried out as according to Bittner and Oke (2006) and were expressed as nanomoles per minute per $\mathrm{OD}_{595} \times 1,000$.

\section{ACKNOWLEDGMENTS}

This research was supported by a United States Department of Agriculture National Institute of Food and Agriculture grant 2015-67013-22837 to M. Teplitski and M. Gao. We gratefully acknowledge technical assistance by A. Benge and J. Mesa, who were both supported by University of Florida's Institute of Food and Agricultural Sciences summer internships.

\section{LITERATURE CITED}

Ampe, F., Kiss, E., Sabourdy, F., and Batut, J. 2003. Transcriptome analysis of Sinorhizobium meliloti during symbiosis. Genome Biol. 4:R15.

Barnett, M. J., Fisher, R. F., Jones, T., Komp, C., Abola, A. P., BarloyHubler, F., Bowser, L., Capela, D., Galibert, F., Gouzy, J., Gurjal, M., Hong, A., Huizar, L., Hyman, R. W., Kahn, D., Kahn, M. L., Kalman, S., Keating, D. H., Palm, C., Peck, M. C., Surzycki, R., Wells, D. H., Yeh, K. C., Davis, R. W., Federspiel, N. A., and Long, S. R. 2001. Nucleotide sequence and predicted functions of the entire Sinorhizobium meliloti pSymA megaplasmid. Proc. Natl. Acad. Sci. U.S.A. 98:9883-9888.

Barra-Bily, L., Pandey, S. P., Trautwetter, A., Blanco, C., and Walker, G. C. 2010. The Sinorhizobium meliloti RNA chaperone Hfq mediates symbiosis of S. meliloti and alfalfa. J. Bacteriol. 192:1710-1718.

Baumgardt, K., Charoenpanich, P., McIntosh, M., Schikora, A., Stein, E., Thalmann, S. 2014. RNase E affects the expression of the acyl-homoserine lactone synthase gene sinI in Sinorhizobium meliloti. J. Bacteriol. 196:1435-1447.

Becker, A., Berges, H., Krol, E., Bruand, C., Ruberg, S., Capela, D., Lauber, E., Meilhoc, E., Ampe, F., de Bruijn, F. J., Fourment, J., Francez-Charlot, A., Kahn, D., Küster, H., Liebe, C., Pühler, A., Weidner, S., and Batut, J. 2004. Global changes in gene expression in Sinorhizobium meliloti 1021 under microoxic and symbiotic conditions. Mol. Plant-Microbe Interact. 17:292-303.

Beringer, J. E. 1974. R Factor transfer in Rhizobium leguminosarum. J. Gen. Microbiol. 84:188-198.

Bittner, A. N., and Oke, V. 2006. Multiple groESL operons are not key targets of RpoH1 and RpoH2 in Sinorhizobium meliloti. J. Bacteriol. 188:3507-3515.

Bobik, C., Meilhoc, E., and Batut, J. 2006. FixJ: A major regulator of the oxygen limitation response and late symbiotic functions of Sinorhizobium meliloti. J. Bacteriol. 188:4890-4902.

Brennan, R. G., and Link, T. M. 2007. Hfq structure, function and ligand binding. Curr. Opin. Microbiol. 10:125-133. 
Caetano-Anollés, G., and Bauer, W. D. 1988. Feedback regulation of nodule formation in alfalfa. Planta 175:546-557.

Cutting, J. A., and Schulman, H. M. 1971. The biogenesis of leghemoglobin. The determinant in the Rhizobium-legume symbiosis for leghemoglobin specificity. Biochim. Biophys. Acta 229:58-62.

David, M., Daveran, M. L., Batut, J., Dedieu, A., Domergue, O., Ghai, J., Hertig, C., Boistard, P., and Kahn, D. 1988. Cascade regulation of nif gene expression in Rhizobium meliloti. Cell 54:671-683.

De Lay, N., Schu, D. J., and Gottesman, S. 2013. Bacterial small RNAbased negative regulation: Hfq and its accomplices. J. Biol. Chem. 288: 7996-8003.

del Val, C., Rivas, E., Torres-Quesada, O., Toro, N., and Jimenez-Zurdo, J. I. 2007. Identification of differentially expressed small non-coding RNAs in the legume endosymbiont Sinorhizobium meliloti by comparative genomics. Mol. Microbiol. 66:1080-1091.

Djordjevic, M. A. 2004. Sinorhizobium meliloti metabolism in the root nodule: A proteomic perspective. Proteomics 4:1859-1872.

Finan, T. M., Kunkel, B., De Vos, G. F., and Signer, E. R. 1986. Second symbiotic megaplasmid in Rhizobium meliloti carrying exopolysaccharide and thiamine synthesis genes. J. Bacteriol. 167:66-72.

Finan, T. M., Mcwhinnie, E., Driscoll, B., and Watson, R. J. 1991. Complex symbiotic phenotypes result from gluconeogenic mutations in Rhizobium meliloti. Mol. Plant-Microbe Interact. 4:386-392.

Fischer, H. M. 1994. Genetic regulation of nitrogen fixation in rhizobia. Microbiol. Rev. 58:352-386.

Gao, M., and Teplitski, M. 2008. RIVET-a tool for in vivo analysis of symbiotically relevant gene expression in Sinorhizobium meliloti. Mol. Plant-Microbe Interact. 21:162-170.

Gao, M., Chen, H., Eberhard, A., Gronquist, M. R., Robinson, J. B., Rolfe, B. G., and Bauer, W. D. 2005. sinI- and expR-dependent quorum sensing in Sinorhizobium meliloti. J. Bacteriol. 187:7931-7944.

Gao, M. S., Barnett, M. J., Long, S. R., and Teplitski, M. 2010. Role of the Sinorhizobium meliloti global regulator $\mathrm{Hfq}$ in gene regulation and symbiosis. Mol. Plant-Microbe Interact. 23:355-365.

Gao, M., Tang, M., Guerich, L., Salas-Gonzalez, I., and Teplitski, M. 2015. Modulation of Sinorhizobium meliloti quorum sensing by Hfq-mediated post-transcriptional regulation of ExpR. Environ. Microbiol. Rep. 7:148154.

Gibson, K. E., Kobayashi, H., and Walker, G. C. 2008. Molecular determinants of a symbiotic chronic infection. Annu. Rev. Genet. 42:413-441.

Gong, Z. Y., He, Z. S., Zhu, J. B., Yu, G. Q., and Zou, H. S. 2006. Sinorhizobium meliloti nifA mutant induces different gene expression profile from wild type in alfalfa nodules. Cell Res. 16:818-829.

Hirsch, A. M., and Smith, C. A. 1987. Effects of Rhizobium meliloti nif and fix mutants on alfalfa root nodule development. J. Bacteriol. 169:1137-1146.

Kaminski, P. A., Desnoues, N., and Elmerich, C. 1994. The expression of nifA in Azorhizobium caulinodans requires a gene product homologous to Escherichia coli HF-I, an RNA-binding protein involved in the replication of phage Q beta RNA. Proc. Natl. Acad. Sci. U.S.A. 91:4663-4667.

Kovach, M. E., Elzer, P. H., Hill, D. S., Robertson, G. T., Farris, M. A., Roop, R. M., II, and Peterson, K. M. 1995. Four new derivatives of the broad-host-range cloning vector $\mathrm{pBBR} 1 \mathrm{MCS}$, carrying different antibioticresistance cassettes. Gene 166:175-176.

Link, T. M., Valentin-Hansen, P., and Brennan, R. G. 2009. Structure of Escherichia coli $\mathrm{Hfq}$ bound to polyriboadenylate RNA. Proc. Natl. Acad. Sci. U.S.A. 106:19292-19297.

Livak, K. J., and Schmittgen, T. D. 2001. Analysis of relative gene expression data using real-time quantitative PCR and the $2^{-\Delta \Delta C(T)}$ method. Methods 25:402-408.

Lodwig, E. M., Hosie, A. H., Bourdes, A., Findlay, K., Allaway, D., Karunakaran, R., Downie, J. A., and Poole, P. S. 2003. Amino-acid cycling drives nitrogen fixation in the legume-Rhizobium symbiosis. Nature 422:722-726.
Long, S. R. 2001. Genes and signals in the Rhizobium-legume symbiosis. Plant Physiol. 125:69-72.

Pellock, B. J., Teplitski, M., Boinay, R. P., Bauer, W. D., and Walker, G. C. 2002. A LuxR homolog controls production of symbiotically active extracellular polysaccharide II by Sinorhizobium meliloti. J. Bacteriol. 184:5067-5076.

Peters, N. K., Frost, J. W., and Long, S. R. 1986. A plant flavone, luteolin, induces expression of Rhizobium meliloti nodulation genes. Science 233: 977-980.

Robinson, K. E., Orans, J., Kovach, A. R., Link, T. M., and Brennan, R. G. 2014. Mapping Hfq-RNA interaction surfaces using tryptophan fluorescence quenching. Nucleic Acids Res. 42:2736-2749.

Schumacher, M. A., Pearson, R. F., Moller, T., Valentin-Hansen, P., and Brennan, R. G. 2002. Structures of the pleiotropic translational regulator Hfq and an Hfq-RNA complex: A bacterial Sm-like protein. EMBO J. 21:3546-3556.

Schwab, K. J., Estes, M. K., Neill, F. H., and Atmar, R. L. 1997. Use of heat release and an internal RNA standard control in reverse transcription-PCR detection of Norwalk virus from stool samples. J. Clin. Microbiol. 35:511-514.

Sharma, C. M., Papenfort, K., Pernitzsch, S. R., Mollenkopf, H. J., Hinton, J. C. D., and Vogel, J. 2011. Pervasive post-transcriptional control of genes involved in amino acid metabolism by the Hfq-dependent GcvB small RNA. Mol. Microbiol. 81:1144-1165.

Soper, T., Mandin, P., Majdalani, N., Gottesman, S., and Woodson, S. A. 2010. Positive regulation by small RNAs and the role of Hfq. Proc. Natl. Acad. Sci. U.S.A. 107:9602-9607.

Torres-Quesada, O., Oruezabal, R. I., Peregrina, A., Jofre, E., Lloret, J., Rivilla, R., Toro, N., Jiménez-Zurdo, J. I. 2010. The Sinorhizobium meliloti RNA chaperone Hfq influences central carbon metabolism and the symbiotic interaction with alfalfa. BMC Microbiol. 10:71.

Torres-Quesada, O., Reinkensmeier, J., Schluter, J. P., Robledo, M., Peregrina, A., Giegerich, R., Toro, N., Becker, A., Jiménez-Zurdo, J. I. 2014. Genome-wide profiling of Hfq-binding RNAs uncovers extensive post-transcriptional rewiring of major stress response and symbiotic regulons in Sinorhizobium meliloti. RNA Biol. 11:563-579.

Vasse, J., de Billy, F., Camut, S., and Truchet, G. 1990. Correlation between ultrastructural differentiation of bacteroids and nitrogen fixation in alfalfa nodules. J. Bacteriol. 172:4295-4306.

Voss, B., Holscher, M., Baumgarth, B., Kalbfleisch, A., Kaya, C., Hess, W. R., Becker, A., and Evguenieva-Hackenberg, E. 2009. Expression of small RNAs in Rhizobiales and protection of a small RNA and its degradation products by Hfq in Sinorhizobium meliloti. Biochem. Biophys. Res. Commun. 390:331-336.

Wilms, I., Voss, B., Hess, W. R., Leichert, L. I., and Narberhaus, F. 2011. Small RNA-mediated control of the Agrobacterium tumefaciens GABA binding protein. Mol. Microbiol. 80:492-506.

Yurgel, S. N., and Kahn, M. L. 2004. Dicarboxylate transport by rhizobia. FEMS Microbiol. Rev. 28:489-501.

Zhang, Y., and Hong, G. 2009. Post-transcriptional regulation of NifA expression by Hfq and RNase E complex in Rhizobium leguminosarum bv. viciae. Acta Biochim. Biophys. Sin. (Shanghai) 41:719-730.

Zhang, A., Wassarman, K. M., Ortega, J., Steven, A. C., and Storz, G. 2002. The Sm-like Hfq protein increases OxyS RNA interaction with target mRNAs. Mol. Cell 9:11-22.

Zimmerman, J. L., Szeto, W. W., and Ausubel, F. M. 1983. Molecular characterization of Tn5-induced symbiotic (Fix ${ }^{-}$) mutants of Rhizobium meliloti. J. Bacteriol. 156:1025-1034.

\section{AUTHOR-RECOMMENDED INTERNET RESOURCE}

LIPM Bioinformatics S. meliloti 1021 webpage:

https://iant.toulouse.inra.fr/bacteria/annotation/cgi/rhime.cgi 